Under the formation of communicative-speaking competence of the future social worker, we understand a complex concept. It includes: personal component, that is maturity of personal qualities, first of all, such as professional values and motives, empathy, tolerance, humanity. Professional component, which includes mastering a future employee of the whole complex of special knowledge, skills, professionalactions. Knowledge of the conceptual terminological apparatus of communicative-speaking competence, ability to analyze a communicative situation, to design and analyze it, to exercise reflection and self-esteem. In addition, it includes individual style of communication, as well as activity of the person, providing realization of the gained experience in communicative-speaking activity and further professional improvement.

Based on defined criteria there were selected appropriate tasks, questionnaires and methods in order to identify the levels of communication skills of future social workers.

Indicators, which are developed for each criterion, take into account the amount of knowledge acquired by students during previous years of higher education, the practical skills and skills that allow them to characterize their behavior in situations relevant to the future profession, as well as reflect the persistence of the identified.

High-quality analysis of the results of the development of communicative-speaking competence in the students of the experimental and control groups showed in the majority of satisfactory and low levels. That do not meet the requirements of professional training of future social workers and indicates the need for purposeful work with students in order to improve their communicative-speaking competence in higher education.

Key words levels of formation, communicative-speaking speech competence, indicators, criteria, future social workers.

Удк 37.011.3:372.461

Вікторія Будянська

Харківський національний економічний університет

імені Семена Кузнеця

ORCID ID 0000-0003-0621-4571

Галина Мариківська

Харківський національний університет внутрішніх справ

ORCID ID 0000-0001-9561-9292

DOI 10.24139/2312-5993/2019.07/172-184

\title{
УДОСКОНАЛЕННЯ ОРАТОРСЬКОЇ МАЙСТЕРНОСТІ МАЙБУТНІХ ПРАВОЗАХИСНИКІВ НА ЗАНЯТТЯХ З УКРАЇНСЬКОЇ МОВИ ПРОФЕСІЙНОГО СПРЯМУВАННЯ В ЗАКЛАДАХ ВИЩОЇ ОСВІТИ
}

\begin{abstract}
Метою статті $\epsilon$ показ шляхів удосконалення ораторської майстерності майбутніх правозахисників у закладах вищої освіти. Було застосовано такі методи дослідження: порівняльно-зіставний, поняттєво-термінологічний аналіз, систематизація та узагальнення. Реалізація завдання розвитку красномовності майбутніх правозахисників має передбачати розкриття студентам сутності цього поняття, що сприятиме підвищенню інтересу до чієї проблеми й активізації зусиль студентів у цьому напрямі. Перспективним напрямом нашого дослідження ми вважаємо розробку вправ і завдань для студентів будь-якого профрілю навчання (зокрема правозахисників), а також для викладачів закладів вищої освіти для вдосконалення їхньої красномовності.
\end{abstract}


Ключові слова: правозахисна діяльність, ораторська майстерність, красномовність, практикум, тренінг, позааудиторна діяльність.

Постановка проблеми. 3 появою суду як елементу демократизації суспільного життя слово правозахисника стало інструментом у відстоюванні закону. Від уміння володіти словом, рівня ораторської культури значною мірою залежить якість правозахисної діяльності. Високою є відповідальність правозахисника перед долею людини, тому він повинен підвищувати свій професіоналізм, удосконалювати ораторське мистецтво. Усі ці фактори підтверджують актуальність обраної теми.

Аналіз актуальних досліджень. Проблема формування ораторських здібностей, риторичної культури цікавила багатьох дослідників: С. Караман розглядав проблему розвитку ораторського мистецтва школярів, О. Кирильчук - проблему формування риторичної культури старшокласників і риторичної майстерності учителів гуманітарних дисциплін, О. Залюбівська риторичної культури майбутніх викладачів технічних університетів, М. Микитюк створив факультативний курс з української мови, з риторики; Л. Введенська, Л. Павлова, С. Гурвич, В. Погорелко присвятили свої дослідження основам риторики.

Метою нашої статті $\epsilon$ показ шляхів удосконалення ораторської майстерності майбутніх правозахисників у закладі вищої освіти.

Для досягнення зазначеної мети визначено такі завдання дослідження: 1) довести необхідність удосконалення ораторської майстерності майбутніх правозахисників на заняттях з української мови професійного спрямування в закладах вищої освіти; 2) зробити аналіз наукової літератури з окресленої проблеми; 3) запропонувати шляхи вдосконалення ораторської майстерності студентів; 4) зробити висновки щодо необхідності вдосконалення ораторської майстерності студентів; 5) визначити перспективні напрями подальших наукових досліджень із зазначеної проблеми.

Розв'язання визначених у статті завдань проводилося шляхом використання комплексу таких методів дослідження: порівняльно-зіставного аналізу - для з'ясування стану розробленості порушеної проблеми, визначення теоретичних засад дослідження, систематизування й узагальнення поглядів науковців; поняттєво-термінологічного - для конкретизації поняттєво-категорійного поля дослідження; систематизації та узагальнення для визначення результатів дослідження та формулювання висновків.

Виклад основного матеріалу. Як зазначено в науковій літературі, багато учнів, які засвоїли лінгвістичний матеріал, відчувають певні труднощі під час реалізації мовленнєвої практики. А тому в процесі педагогічної взаємодії важливо забезпечити не тільки оволодіння ними теоретичними основами мовленнєвої культури, а й навчити їх 
орієнтуватися в конкретних мовленнєвих ситуаціях, підбирати відповідно до них адекватні мовні засоби, правильно застосовувати невербальні мовні засоби (жести, міміку тощо). Це передбачає застосування різних активних та інтерактивних методів навчання. О.Горошкіна конкретизує: учням необхідна «систематична цілеспрямована мовленнєва практика, що ґрунтується на вмінні вибирати потрібні слова, конструкції з урахуванням умов спілкування» (Горошкіна, 2005, с. 16). Для цього слід застосовувати різні активні методи навчання.

Н. Луценко також зазначає, що мовленнєве спілкування відбувається в процесі комунікативно-мовленнєвої діяльності. А для їі успішного здійснення людина має засвоїти не тільки відповідні знання, а й цілу низку найважливіших мовленнєвих умінь, зокрема таких: уміння орієнтуватися в ситуації спілкування залежно від часово-просторових та змістовних особливостей, соціальних ролей співрозмовників та їхніх взаємостосунків, планувати мовленнєву поведінку залежно від статі, віку, соціальної ролі, фізичного та психологічного станів співрозмовника, добору лексичних засобів та граматичних форм, довільного керування невербальними засобами спілкування; уміння правильно використовувати вербальні й невербальні прийоми вступу до мовленнєвого контакту, підтримувати та розвивати діалогічну взаємодію, ввічливе і логічне завершення спілкування, здатність виявляти ініціативу в спілкуванні з дорослими та однолітками, знаходити в колі ровесників партнерів-співрозмовників, пропонувати тему розмови, спрямовувати ії в потрібне русло з урахуванням власних та спільних інтересів; уміння розв'язувати комунікативно-мовленнєві завдання завдяки добору адекватних комунікативній меті та проблемній ситуації засобів; уміння досягати комунікативної мети завдяки комплексному використанню мовленнєвих форм і невербальних засобів, адресованих партнеруспіврозмовнику (Луценко, 2003).

Досконале володіння людиною словом, практичну здатність говорити красиво, логічно, переконливо, уміння однаково добре вимовляти підготовлений текст та імпровізувати з давніх часів пов' язують із такою властивістю людини, як красномовність (походить від слів «червоний» i «мова»). Як відомо, деякі люди мають природний ораторський талант та харизму. Однак, у більшості випадків особистість має цілеспрямовано оволодівати мистецтвом мовлення.

Одним із шляхів формування красномовності школярів і студентів $\epsilon$ використання мовленнєвих ситуацій. За висновками науковців, така ситуація становить ситуацію мовлення, ситуаційний контекст мовленнєвої взаємодії; набір характеристик ситуативного контексту релевантних (значущих) для мовленнєвої поведінки учасників мовленнєвої дії, що впливають на вибір ними мовленнєвих стратегій, прийомів, засобів (Ладыженская, 1998); комплекс позамовних обставин, які відбивають 
стосунки між учасниками спілкування й зумовлюють необхідність комунікації (Демьяненко, 1984); сукупність умов, мовленнєвих і немовленнєвих, необхідних і достатніх, задля того, щоб здійснити мовленнєву дію за накресленим планом (Леонтьев, 1969); сукупність спеціально створених умов (Ляховицький, 1972); ситуацію дійсності, що спонукає до мовлення (Ніколаєва, 2008; Пассов, 1989; Пассов, 1985); динамічну систему взаємовідносин тих, хто спілкується, яка базується на відображенні об'єктів і подій зовнішнього світу, породжує потребу цілеспрямованої діяльності у вирішенні мовленнєво-мисленнєвих завдань і живить цю діяльність (Богуш, 2008).

Під мовленнєвими ситуаціями ми розуміємо сукупність спеціально створених зовнішніх обставин, що спонукають студентів до спілкування та створюють певні відносини між ними. Такі ситуації дають можливість на практиці відпрацювати дотримання загальноприйнятих норм комунікативної поведінки та побудови мовленнєвого процесу.

При цьому важливими вимогами до використання таких ситуацій у педагогічній взаємодії є врахування психологічних особливостей учнів та їхніх зацікавлень, окреслення складових мовленнєвих дій і операцій, застосування елементів інтерактивних методів та інноваційних засобів навчання, що забезпечують активне засвоєння матеріалу й розвиток мовленнєвої культури кожної особистості (Бабич, 1990). Слід також відзначити, що мовленнєві ситуації можна створювати різними способами: за допомогою тексту й допоміжних запитань; наочно (з використанням картин, малюнків, схем); описово (на основі аналогії) тощо (Гладіна, 2009, с. 115).

У науковій літературі також зазначено, що ефективним засобом формування красномовності є виконання спеціальних мовленнєвих вправ та завдань. Мовленнєві вправи - це «вправи в природній комунікації в різних видах мовленнєвої діяльності» (Гез, 1982, с. 193). Важливою особливістю таких вправ $€$ спрямованість на наближення навчальної діяльності учнів до реального спілкування (Богуш, 2008, с. 78).

Зазначимо, що успішне формування красномовності студентів передбачає оптимальне поєднання в системі різних типів та видів вправ. Фахівці висловлюють різні поради щодо відбору цих вправ.

Так, в одному з наукових джерел наголошують, що важливою особливістю процесу використання комунікативних вправ та завдань $€$ застосування наукового дискурсу певного типу та жанру. Як уточнюють у науковій літературі, дискурс - це текст, у якому відбивається ставлення комуніканта до повідомлення, урахування адресата мовлення, мовного оточення, умов спілкування тощо. Отже, «текст - це те, що є продуктом мовлення, а дискурс - це текст, що реалізується через мовлення в поєднанні з позамовними реаліями (Пентилюк, 2011, с. 99). Причому науковий дискурс становить словесне зображення, що спрямоване на вирішення певної проблеми. 
Дослідники також підкреслюють, що для мовленнєвого розвитку студентів велике значення має система таких завдань, яка забезпечувала би пізнання процесів, що відбуваються в мовленні, вироблення усвідомлених мовленнєвих навичок та сприяла розвиткові мовленнєвої культури загалом. Так, Г. Бородіна у своїй статті стверджує, що найбільшу зацікавленість у суб'єктів педагогічної взаємодії та найкращі результати освітньої діяльності забезпечують завдання проблемного характеру. Причому для досягнення високої ефективності проблемні завдання мають містити чітку форму «завдання-запитання», а не «вказівку-виконання». Саме така постановка проблеми забезпечує найефективніше формування мовленнєвої культури суб'єктів (Бородіна, 2009).

Слід зазначити, що значний вплив на розвиток красномовності студентів має також проведення різноманітних виховних заходів, які вимагають від кожного учасника демонстрації мовленнєвих знань та вмінь. Серед цих заходів можна назвати такі: конкурси знавців української мови, літературні вікторини, лінгвістичні ринги, засідання клубу «Що? Де? Коли?», вечори поезії, конкурси читців віршів тощо.

Отже, одним із напрямів формування мовленнєвої культури студентів $\epsilon$ забезпечення цілеспрямованого розвитку в них красномовності. 3 цією метою доцільно розробляти й реалізовувати на практиці відповідну систему вправ і завдань різних типів та видів, проводити спеціальні виховні заходи. Проте в закладах вищої освіти в процесі виконання мовленнєвих завдань практично половина викладачів не ставить перед собою мети забезпечити цілеспрямований розвиток красномовності майбутніх фахівців. Крім того, не проводиться відповідна виховна робота в цьому напрямі.

Реалізація розвитку красномовності студентів передбачає їх спонукання до постійного вправляння в красномовстві. Для цього доцільно в процесі педагогічної взаємодії значну увагу приділяти розкриттю сутності самого поняття красномовності та його ролі в житті сучасної людини. Зокрема, під час проведення однієї з дискусій учням можна запропонувати визначення красномовності різних авторів, наприклад, такі: уміння цікаво та дохідливо донести до слухачів свої думки; ідеальне володіння словом; спроможність оратора говорити на будь-яку тему; уміння однаково добре вимовляти текст, імпровізувати; здатність людини вибудувати аргументовану, переконливу мову; ораторська (риторична) майстерність тощо. Студентам можна запропонувати висловити свої оцінні судження щодо наведених визначень та обрати те з них, яке вони вважають найбільш правильним, точним, а потім аргументувати свою позицію.

Для розвитку мотивації в студентів щодо оволодіння красномовністю доречно стисло висвітлити історію розвитку ораторського мистецтва. Зокрема, ознайомити з тим, що це мистецтво створювалося на теренах 
Вавилону, Стародавньої Греції та Риму. Наприклад, в Елладі, де панував демократичний устрій, найважливіші державні проблеми обговорювалися на публічних зборах. І часто рішення громади формувалося під впливом найкращого оратора, який зумів своєю красномовністю залучити на свій бік більшість людей. Студентам можна розповісти біографію відомого оратора Демосфена, який, не маючи особливих природних мовленнєвих здібностей, виявив силу волі, розвинув ці здібності й став визнаним майстром публічного слова.

Під час слухання лекції студенти дізнаються, що подальший розвиток мистецтва красномовності пов'язаний із історією Давнього Риму, у якому професію ритора вважали в суспільстві однією з найпрестижніших. За античних часів відомий римський оратор Цицерон писав, що майстерність оратора виявляється в його спроможності підкорити увагу слухачів, примусити їх приєднатися до точки зору мовця. Така майстерність, на думку відомого мислителя, забезпечує поєднання в людини таланту філософа, поета, актора та правознавця.

Можна довести студентам, що розвиток ораторського мистецтва в сучасному суспільстві, з одного боку, ґрунтується на традиціях класичної ораторської школи, а з іншого - на новітніх досягненнях психології, логіки, менеджменту й інших наук, що забезпечує найбільш дієвий вплив на слухача. Причому в сучасному інформаційному суспільстві роль красномовності постійно зростає, а тому в багатьох розвинених країнах світу в навчальному плані закладів середньої та вищої освіти місце посідає риторика (Бабич, 1990).

Проведення в закладах вищої освіти такої роботи зі студентами сприятиме підвищенню інтересу до проблеми оволодіння красномовністю та активізації їхніх зусиль у цьому напрямі. Уточнимо, що для розвитку красномовності студентів доцільно проводити різні заходи: міні-лекції, бесіди, обговорення на відповідні теми тощо.

Наприклад, у ході мікролекції на тему «Типи підготовки до публічного виступу» студенти можуть ознайомитися з особливостями трьох типів підготовки до публічного виступу: 1) написання повного тексту промови; 2) запис головних положень (тез чи аргументів); 3) виголошення промови експромтом.

Студенти дійдуть висновку, що перший тип підготовки рекомендують використовувати для відповідальних, офіційних ситуацій, при цьому виступ за попередньо підготовленим текстом може мати три варіанти: читання вголос за рукописом, вивчення та відтворення по пам'яті, виголошення промови з опорою на текст. Викладачу потрібно підкреслити, що найменш прийнятним для успішного публічного виступу $є$ читання готового тексту, який достатньо складно сприймається на слух та примушує промовця зосередитися на тексті. Як наслідок, руйнується контакт із аудиторією. 
Також у лекції можна зазначити, що промова за вивченим напам'ять текстом сприймається оточенням краще, ніж читання тексту, проте теж має багато недоліків. Так, промовець може забути певні фрагменти написаного тексту, що негативно вплине на сприйняття промови. Крім того, під час сприйняття готового тексту аудиторія помічає, що оратор не говорить вільно про порушену проблему, а «механічно» відтворює вже написане.

Студентам також можна нагадати, що виступ досвідчених майстрів слова зазвичай містить елементи живого спілкування з аудиторією, коли ії представники ставлять певні питання чи відбувається обмін думками. Очевидно, що в разі читання промовцем тексту напам'ять спроби слухачів «втрутитися» зі своїми коментарями у виступ можуть «вибити його з колії».

На підставі своїх міркувань викладач підсумовує, що найбільш прийнятною є промова, яку виголошують з опорою на текст. Це дає змогу, з одного боку, дотримуватися загальної канви тексту підготовленого виступу, а з іншого - вносити у свою промову за необхідності відповідні зміни згідно з виявленою аудиторією реакцією. Крім того, такий виступ переконує слухачів у тому, що промовець вільно володіє цим матеріалом, а також ораторським мистецтвом загалом.

До відома студентів потрібно довести, що другий тип підготовки до публічного виступу (запис основних положень) доцільно використовувати досвідченим ораторам, які мають значний досвід виступу перед аудиторією. Для виступу цього типу фахівці рекомендують у письмовій формі підготувати необхідні цитати та цифровий матеріал. Крім того, оратору варто на аркуші записати перші та останні фрази промови, а також занотувати основні тези й аргументи, на яких він збирається сконцентрувати свою увагу.

Як було пояснено студентам, третій тип підготовки передбачає імпровізовану промову. Однак зазвичай кращим експромтом $€$ добре підготовлений експромт. А тому навіть у разі наявності в людини ораторської майстерності їі виступ буде більш переконливим, якщо вона добре розбирається в порушеній проблемі. А це означає, що будь-яка імпровізована промова передбачає проведення попередньої роботи 3 дослідження стану розробленості цієї проблеми, аналізу точок зору фахівців, відпрацювання власних оцінних суджень щодо неї тощо.

Наприкінці міні-лекції студенти під керівництвом викладача мають дійти висновку, що оптимальним варіантом для них $є$ підготовка повного тексту виступу перед аудиторією. Цей текст спочатку доцільно декілька разів прочитати вголос, а потім прорепетирувати свій виступ перед дзеркалом. Корисно також записати ці виступи на аудіо- чи відеоносій, що допоможе своєчасно виявити в них ті чи інші недоліки та ліквідувати їх перед реальною комунікацією.

Для студентів доречно провести також міні-лекції, бесіди на такі теми: «Методика оволодіння ораторським мистецтвом», «Аргументація та 
критика», «Стратегія оратора», «Форми мовленнєвого впливу», «Невербальні засоби оратора». Крім того, студентам можна запропонувати підготовити доповіді та повідомлення на такі теми: «Вибір теми та створення промови», «Тренування мовного апарату», «Розвиток діапазону голосу» тощо. Важливо зауважити, що всі створені викладачами та самими студентами матеріали 3 проблеми формування ораторської майстерності повинні зберігатися в 3ВО, що робить їх доступними для всіх учасників педагогічної взаємодії.

Важливе місце в роботі, спрямованій на оволодіння учнями красномовністю, має бути відведено організації спеціальних практикумів, тренінгів, які сприятимуть засвоєнню риторичних знань на практиці. Зокрема, учні можуть бути залученими до виконання вправ різного типу, спрямованих на оволодіння технікою мовлення.

Наприклад, для розвитку фонаційного дихання студентам можна запропонувати такі вправи:

1) «Видих», під час виконання якої роблять глибокий енергійний вдих через ніс і довгий рівномірний активний видих, сфокусований на кінчиках губ;

2) «Ракета», під час виконання якої повільно відлічують час від десяти до одного до подання команди «зліт»;

3) «Свічка», під час виконання якої людина з відстані півметра мала «покласти» полум'я свічки горизонтально, а потім, не добираючи повітря, загасити його.

Студентам також можна запропонувати вправи для розвитку посилу звуку, наприклад, вправа «настільний теніс». Під час ії виконання учасник, уявляючи кисть своєї руки ракеткою від настільного тенісу, має тренувати удари та відповідно озвучувати їх: ппа...! ппе...! ппо...!, ппи...! тощо. При цьому звуки мають посилатися в різні точки кімнати: уверх, уперед, праворуч, ліворуч, униз.

Студентам також можна запропонувати вправи для розвитку сили і гнучкості голосу, зокрема вправа «їхали». Ії̈ виконавці мають вимовляти слова спочатку поволі, потім поступово прискорювати темп до дуже швидкого з подальшим уповільненням: «Швидко їхали, швидко їхали, швидко їхали... швидко їхали... швидко їхали».

Звернемо увагу, що важливе значення мають вправи, спрямовані на покращення дикції. Наприклад, студенти можуть виконати вправу «Сполучення», яка передбачає відпрацювання ними вимовляння різних сполучень приголосних п, т, х, ч, к, ш, поєднуючи від двох до чотирьох наведених звуків. Причому викладачам важливо стежити, щоб під час виконання вправи не вимовлялися голосні звуки.

Значне місце в запропонованому комплексі вправ має бути відведено також вправам для розвитку інших важливих мовних характеристик голосу: висоти, благозвучності, рухливості, тональності 
тощо. Наприклад, серед цієї групи вправ можна назвати вправу «Трансляція». Під час її виконання потрібно відповідно до авторських ремарок прочитати вголос такий текст:

Прийшла?! Мені страшно за тебе! (Зі страхом). У всьому вини саму себе! (Зі страхом). Прийшла?! А самолюбство де? (/з засудженням). За ним як вірний пес скрізь! (Із засудженням). Прийшов!? Так обдурити мене! (3 презирством). Ти не мужик, а розмазня! (3 презирством). Прийшов?! Ось і попався, друже! (3 єхидством). Адже мене не обдуриш раптом! (3 єхидством). Прийшла! Знати, так тому і бути! (3 радістю). Нам одне без одного не прожити! (3 радістю). Пішов! Прийде або ні? Загадка (3 тривогою). Я поступила з ним так бридко! (3 тривогою). Пішов! Гора звалилася з плечей! (3 полегшенням). Боже борони від цих зустрічей! (3 полегшенням).

Під час виконання іншої вправи - «Інтонація» - студенти мають прочитати певну фразу (наприклад, таку: «Після закінчення закладу вищої освіти я буду працювати адвокатом») з різною інтонацією: бадьоро, упевнено, байдуже, з подивом, із сумлінням, запитливо тощо.

Зазначимо, що деякі запропоновані вправи мають бути спрямовані на відпрацювання правильного логічного наголосу. Зокрема вправа «Інтонація» передбачає, що студенти читають написане на дошці речення (наприклад, таке: «У майбутньому ми станемо кваліфікованими фахівцями»), виокремлюючи в ньому інтонаційно різні слова.

Значний інтерес у студентів має викликати вправа «Ледве», під час виконання якої потрібно прочитати запропонований вірш у заданому темпі:

Ледве-ледве, ледве-ледве (повільний темп)

Завертілись каруселі (повільний темп)

А потім, потім, потім (середній темп)

Все бігом, бігом, бігом! (швидкий темп)

Все швидше, швидше, бігом (дуже швидкий темп)

Карусель довкруги, довкруги! (дуже швидкий темп)

Тихіше, тихіше, не поспішаєте (середній темп)

Карусель зупините (середній темп)

Раз, два, раз, два (повільний темп)

Ось і скінчилась гра (повільний темп).

Особливе місце серед запропонованих студентам вправ мають посісти вправи, спрямовані на засвоєння невербальної техніки мовлення. Наприклад, під час виконання вправ «Розділіть радість» та «Розділіть горе» студентам, які працюють у парах, можна запропонувати за допомогою використання різних невербальних засобів мовлення продемонструвати своїм співрозмовникам відповідні ситуації емоції, розуміння та психологічну підтримку. 
Важливо підкреслити, що студенти спочатку мають виконувати запропоновані вправи під керівництвом викладача. Пізніше ці вправи доречно пропонувати робити вдома самостійно.

Засвоєння техніки мовлення $€$ важливим кроком на шляху до оволодіння студентами ораторською майстерністю. Наступний етап на цьому шляху - залучення їх до творчої мовленнєвої діяльності в межах спеціально змодельованих ситуацій. 3 цією метою можна запропонувати студентам виконати різні завдання.

Так, під час виконання завдання «Розповідь» студентам можна запропонувати без попередньої підготовки підготувати 3-хвилинну розповідь на визначену тему: «Сучасний заклад вищої освіти», «Моя майбутня професія», «Справжня дружба» тощо. Завдання «Канон» передбачає, щоб у процесі його виконання студенти по черзі починали читати напам'ять добре знайомий їм вірш, намагаючись не порушити певного темпу. Під час виконання завдання «Предметний монолог» студенти протягом декількох хвилин мають демонструвати вільний монолог від заданого предмета: стола, підручника, комп'ютера тощо. У ході виконання завдання «Впізнай актора» студенти мають втілитися в обраного ними відомого актора та від його імені, копіюючи його характерні інтонації й жести, упродовж п'яти хвилин розповідати про себе чи говорити на будь-яку іншу тему.

Студентам також можна запропонувати виконати завдання «Інтерв'ю», коли один із учасників грає роль певної публічної особи та від ії імені дає інтерв'ю решті молодих людей, які перевтілюються в журналістів. Під час виконання завдання «Самопрезентація» кожний студент має підготувати самопрезентацію, у якій зміг би повною мірою розкрити свої таланти та кращі особистісні якості.

Зауважимо, що подальша робота з розвитку красномовності студентів має охоплювати заняття з різних навчальних дисциплін. При цьому значне місце на заняттях має відводитися виступам учнів із повідомленнями чи невеликими доповідями, обговоренню певних складних проблем, організації диспутів та дискусій. Зокрема, у процесі здійснення педагогічної взаємодії викладачі повинні спонукати студентів до формулювання власних суджень та оцінок щодо порушених проблем, підбору переконливих аргументів для доведення правильності власної точки зору.

Слід зазначити, що розвиток красномовності студентів має відбуватися й під час проведення позааудиторної роботи. Причому студентам потрібно надавати можливість брати участь як у спеціально організованих для них заходах, так і у виховних заходах, які проводяться для студентів. Зокрема, вечори поезії, конкурси читців віршів, есе та інших написаних студентами творів. Наприклад, для студентів доцільно провести вечір поезії, присвячений творчості Ліни Костенко. Одним із етапів цього вечора має бути конкурс читців віршів цієї відомої поетеси. 
Значний інтерес у студентів має викликати також вечір поезії, присвячений творчості Тараса Шевченка. У межах проведення цього вечора можна провести конкурс читців.

Висновки. Залучення студентів до описаної виховної роботи сприятиме розвитку красномовності, збагатить їхній досвід публічних виступів, підвищить упевненість у своїх силах.

Слід також зазначити, що для активізації розвитку в студентів красномовності викладачі мають залучати їх до виконання індивідуальних навчально-дослідних проектів на різну тематику.

Під час роботи над навчально-дослідним проектом учням потрібно надати необхідну педагогічну підтримку з боку викладачів. Результати виконання такого проекту потрібно оформити студентам у формі доповіді, відеопрезентації тощо. Після цього кожному досліднику потрібно надати можливість коротко репрезентувати результати своєї роботи студентській аудиторії. Наприкінці виступу має бути організована дискусія, у процесі якої кожний, хто бажає, може висловити власні думки щодо змісту почутої доповіді, відзначити її основні переваги й недоліки.

Отже, постійне вправляння в красномовстві студентів сприятиме формуванню вміння орієнтуватися в ситуаціях спілкування, добирати потрібні лексичні засоби та граматичні форми, довільно керувати невербальними засобами спілкування, вести діалог тощо.

Перспективи подальших наукових розвідок. Перспективним напрямом нашого дослідження ми вважаємо розробку вправ і завдань для студентів будь-якого профілю навчання (зокрема правозахисників), що доцільно застосовувати в процесі вдосконалення навичок красномовності. Також перспективним напрямом дослідження ми вважаємо розробку вправ і завдань для викладачів закладів вищої освіти, що також можна застосовувати для вдосконалення їхньої красномовності.

\section{ЛITЕРАТУРА}

Аверинцев, С. С. (1984). Эволюция философской мысли. Москва: Наука (Averintsev, S. S. (1984). The evolution of philosophical thought. M oscow: Science).

Бабич, Н. Д. (1990). Основи культури мовлення. Львів: Світ (Babych, N. D. (1990). Fundamentals of Speech Culture. Lviv: The World).

Богуш, А. М. (2008). Мовленнєво-ігрова діяльність дошкільників: мовленнєві ігри, ситуації, вправи. Київ: Видавничий Дім «Слово» (Bogush, А. М. (2008). Speech and play activities of preschoolers: speech games, situations, exercises. Kiev: "Word" Publishing House).

Бородіна, Г.І.(2009). Комунікативні завдання на базі професійно-орієнтованого тексту при навчанні ESP. Харків: Вісник ХНУ (Borodina, Н. І. (2009). Communicative tasks based on vocationally-oriented text in learning ESP. Kharkov: Bulletin of $\mathrm{KhNU}$ ).

Гладіна, Г. І. (2009). Комунікативні вправи як засіб закріплення мовного матеріалу. збірник наукових праць Бердянського державного педагогічного університету. 
Педагогічні науки, Вип. 2, 113-117 (Hladina, H. I. (2009). Communicative exercises as a means of securing language material. Collection of scientific works of Berdyansk State Pedagogical University. Pedagogical Sciences, Issue 2, 113-117).

Гойхман, О. Я. (2003). Русский язык и культура речи. Москва: ИНФРА (Hoichman, О. Үа. (2003). Russian language and speech culture. M oscow: INFRA).

Горошкіна, О. М. (2005). Методика навчання української мови в загальноосвітніх навчальних закладах III-го ступеня природничо-математичного профрілю (автореф. дис. ... канд. пед. наук: 13.00.02). Київ (Horoshkina, О. М. (2005). Methods of teaching Ukrainian language in general education institutions of the III degree of natural-mathematical profile (PhD thesis abstract). Kyiv).

Демьяненко, М. Я. (1984). Основы общей методики обучения иностранным языкам. Киев: Вища школа (Demianenko, М. Ү. (1984). Basics of the general methodology of teaching foreign languages. Kyiv: Higher school).

Леонтьев, А.А. (1969). Язык, речь, речевая деятельность. Москва: Просвещение (Leontiev, A. A. (1969). Language, speech, speech activity. M oscow: Enlightenment).

Луценко, Н. (2003). Введение в лингвистику слова. Горловка: Издательство ГгПИИя (Lutsenko, N. (2003). Introduction to word linguistics. Horlovka: Publishing House of the State Geographic Institute).

Ляховицький, М. В. (1972). Основні принципи побудови підручників і навчальних посібників з іноземної мови для шкіл УРСР. Київ: Рад. школа (Lakhovitskyi, M. V. (1972). Basic principles for the construction of textbooks and tutorials in foreign languages for schools of the USSR. Kyiv: Soviet school).

Методика обучения иностранным языкам в средней школе (1982). (Н. И. Гез, М. В. Ляховский, А. А. Миролюбов и др). Москва: Высшая школа (M ethods of teaching foreign languages in higher school (1982). (N. I. Gez, M. V. Liakhovskyi, A. A. Miroliubov, etc.). Moscow: Higher school).

Ніколаєва, С. Ю. (2008). Методика навчання іноземних мов у середніх навчальних закладах. Київ: Ленвіт (Nikolaiev, S. Yu. (2008). Methods of teaching foreign languages in secondary schools. Kyiv: Lenvit).

Пасинок, В.Г. (2011). Основи культури мовлення. Харків: ХН. (Pasynok, V. Н. (2011). Fundamentals of speech culture. Kharkiv: KhNU).

Пассов, Е.И. (1989). Основы коммуникативной методики обучения иноязычному общению. Москва: Русский язык (Passov, Yе. І. (1989). Basics of communicative teaching methodology for foreign language communication. M oscow: Russian language).

Пассов, Е. И. (1985). Теоретические основы обучения иностранному говорению. Москва: Просвещение (Passov, Ye. I. (1985). Theoretical foundations of teaching foreign language. M oscow: Enlightenment).

Педагогическое речеведение. Словарь-справочник. (1998). Москва: Флинта, Наука (Pedagogical speech. Directory dictionary. (1998). M oscow: Flint, Science).

Пентилюк, М.І. (2011). Актуальні проблеми сучасної лінгводидактики. Київ: Ленвіт (Pentyluk, M. I. (2011). Actual problems of modern linguistics. Kyiv: Lenvit).

\section{PEЗЮME}

Будянская Виктория, Марыкивская Галина. Совершенствование ораторского мастерства будущих правозащитников на занятиях по украинскому языку профессионального направления в учреждениях высшего образования.

Целью статьи является показ пути совершенствования ораторского мастерства будущих правозащитников в учреждениях высшего образования. Были использованы такие методы исследования: сравнительно-сопоставительный, 
понятийно-терминологический анализ, систематизация и обобщение. Реализация задачи развития красноречия будущих правозащитников должна предусматривать раскрытие студентам сущности этого понятия, что будет способствовать повышению интереса к этой проблеме и активизации усилий студентов в этом направлении. Перспективным направлением исследования мы считаем разработку упражнений и заданий для студентов любого профиля обучения (в том числе правозащитников), а также для преподавателей высших учебных заведений для совершенствования их красноречия.

Ключевые слова: правозащитная деятельность, ораторское мастерство, красноречие, практикум, тренинг, внеаудиторная деятельность.

\section{SUMMARY}

Buclanska Viktoria, Marikivska Halyna. Improvement of speakers' skills of future law enforcers at the classes of Ukrainian language with professional direction in higher education institutions.

The purpose of our article is to demonstrate ways to improve the speakers' skills of future law enforcers in higher education institutions.

To achieve this goal, the following research objectives have been identified: 1) to prove the need to improve the speakers' skills of future law enforcers in the Ukrainian language vocational training courses in higher education institutions; 2) to analyze the scientific literature on the outlined problem; 3) to propose ways to improve the speakers' skills of students; 4) to make conclusions about the need to improve the speakers' skills of students; 5) to identify promising areas for further research on the problem.

The tasks defined in the article were solved by using a complex of the following methods of research: theoretical: comparative-contrastive analysis - to find out the state of elaboration of the problem raised, to determine the theoretical foundations of the research, to systematize and generalize the views of scientists; conceptual-terminological - for specification of conceptual-categorical field of research; systematization and generalization to determine the results of the study and formulate conclusions.

Realization of the task of developing the eloquence of future law enforcers should provide students with an idea of this concept, which will increase the interest in this problem and intensify the efforts of students in this direction. For this purpose, it is advisable to conduct mini-lectures, interviews, discussions on the topic. An important place in the work should be given to organization of special workshops, trainings that will facilitate assimilation of rhetorical knowledge in practice. The development of eloquence must also occur during extra-curricular work - in the process of conducting poetry evenings, poetry readers' competitions, essays and other works. To enhance development of eloquence in students, teachers should involve them in the implementation of individual research projects.

We believe that constant exercise in the eloquence of students will promote formation of the ability to navigate communication situations, to find the necessary lexical means and grammatical forms, to arbitrarily manage non-verbal means of communication, to engage in dialogue, etc.

A promising area of our research is development of exercises and tasks for students of any training profile (including law enforcers), which should be used in the process of improving eloquence skills. Also, we consider development of exercises and tasks for higher education teachers to be a promising area of research, which can also be used to improve their eloquence

Key words law enforcing activities, speakers' skills, eloquence, practicum, training, extra-curricular activities. 